\title{
Jawność rozprawy głównej a gwarancje przewidziane w Konstytucji
}

\begin{abstract}
The principle of openness, as one of the foremost principles of criminal proceedings, is realised above all during the main trial. The amendment act of law to the code of criminal procedure issued on 10 June 2016 introduced model changes in this regard. The article is devoted to a discussion of mainly these changes in the context of their consistency with the Constitution. The first change has to do with the fact that the public prosecutor has the right to express his or her objection toward the holding of a trial in camera, while such an objection is binding for the court. This regulation is a source of reservations of constitutional nature, for it violates the constitutional right to a fair adjudication of a case by the court. The second fundamental change consists in the establishment, as a principle, of audio-visual registering of the court session by the representatives of media outlets. In these terms, a critical analysis should be conducted upon the removal of the condition of the respect of the important interest of the participant of a criminal proceeding. However, a basically positive evaluation was received by the extension of the scope of the openness of the main trial, expressing a thesis about the constancy of this regulation with the Constitution.
\end{abstract}

Key words: openness, main trial, guarantees, the Constitution, criminal procedure

Zasada jawności jest trwałym elementem struktury procesu karnego, objętym powszechną afirmacją. Jakiekolwiek próby dezawuowania lub obniżania jej wartości i znaczenia, a w konsekwencji relatywnego rugowania jej z procesu karnego z góry są skazane na niepowodzenie, bo nie miałyby żadnego racjonalnego i aksjologicznego uzasadnienia.

Bezsprzeczna i zarazem szczególna rola jawności jest wyeksponowana w wypadku rozprawy głównej. W państwie demokratycznym jest ona z natury rzeczy otwarta dla społeczeństwa - albo poprzez dopuszczenie reprezentacji społecznej obserwującej bezpośrednio jej przebieg (reguła publiczności), albo w wyniku umożliwienia dziennikarzom relacjonowa- 
nia przebiegu rozprawy, a tym samym pełnienia funkcji swoistych pośredników między procesem a społeczeństwem. W obu aspektach jawności zewnętrznej punktem odniesienia uzasadniającym udostępnienie procesu dla społeczeństwa jest przede wszystkim fundamentalny interes zbiorowości w weryfikowaniu prawidłowego wykonywania władzy sądowej, a nawet można twierdzić, że chodzi tutaj także o ochronę tej zbiorowości w sensie zapobiegania kontynuacji działalności przestępczej przez oskarżonych $^{1}$. System demokracji politycznej nie tylko bowiem zezwala na kontrolę władzy publicznej sprawowaną przez opinię publiczną, ale wręcz tej kontroli wymaga. W tym kontekście trudno sobie wyobrazić nadmierne ograniczenie swoistego prawa społecznego do kroniki sądowej i prawa do krytyki. Gdyby to miało nastąpić, odbiłoby się negatywnie na potrzebie przejrzystości w wykonywaniu przez sąd funkcji jurysdykcji karnej, co odczuliby zarówno uczestnicy procesowi bezpośrednio uwikłani w zdarzenie sądowe, jak i obywatele neutralni względem procesu ${ }^{2}$. Nie dziwi więc fakt, że jawność jest tradycyjnie zaliczana w poczet gwarancji sprawiedliwości i wolności, ponadto tworzy także dla oskarżonego ochronę przed bezprawnością i stronniczością, skoro reprezentuje jeden ze środków prawnych ukierunkowanych na zagwarantowanie zaufania do wymiaru sprawiedliwości, a poza tym, z powodu owej transparentności, jaką nadaje działalności sądowej, przyczynia się do realizacji idei rzetelnego procesu ${ }^{3}$. Nie da się więc zakwestionować tezy, że jawność rozprawy głównej jest inspirowana nie tylko potrzebami zbiorowości, ale także koniecznością poszanowania interesu indywidualnego.

Co ważne, tak nakreślona podstawowa rola pełniona przez jawność nie może powodować niemożności wprowadzenia jej ograniczeń, gdy w grę wchodzą dobra lub wartości pozostające wprawdzie w sytuacji kolizyjnej, ale zarazem o analogicznej doniosłości ${ }^{4}$. Skoro bowiem zasada jawności w całej swej rozciągłości zmierza do realizacji możliwości poznania przez każdego działalności rozwijanej w interesie wszystkich, ta perspektywa stanowi zawsze punkt wyjścia podczas konstruowania stosownych ograniczeń. Konkluzja, jaka się pojawia w tego typu rozważaniach, musi być więc zawsze tożsama: tylko kwestia granic respektowania jawności

${ }^{1}$ D. Manzione. W: Commento al nuovo codice di procedura penale, Red. M. Chiavario. T. V. Torino 1991, s. 59; R. Bianco: Il diritto del giornalismo. Padova 1997, s. 64; M. MERCone: Diritto processuale penale. Milano 2000, s. 60.

${ }^{2}$ L. GIULIANI: Rimessione del processo e valori costituzionali. Torino 2002, s. 197.

${ }^{3}$ Wyrok ETPC z dnia 8 grudnia 1983 r., cytowany i omówiony w: G. UbERTIs: Principi di procedura penale europea. Le regole del giusto processo. Milano 2000, s. 29. O tej podwójnej wartości jawności wspomina także m.in. M. CiapPI: Pubblicità (principio della). „Digesto delle Discipline Penalistiche” 1995, nr 10, s. 458.

${ }^{4}$ L. Scomparin: La tutela del testimone nel processo penale. Padova 2000, s. 135. 
w ogóle, w tym jawności rozprawy głównej, może być przedmiotem sporów mieszczących się w ramach racjonalnej i dopuszczalnej dyskusji.

Jest rzeczą oczywistą, że zakres dopuszczalnych ograniczeń jawności rozprawy głównej wyznaczają w pierwszej kolejności normy zawarte w konstytucji. Najwyższa moc prawna konstytucji i jej największa siła oddziaływania promieniująca na cały porządek prawny stanowią zasadnicze determinanty przyznania konstytucji szczególnej roli w systemie prawnym. W rezultacie ostatecznie w normach konstytucyjnych poszukujemy zawsze potwierdzenia wartości danej regulacji ustawowej albo wręcz przeciwnie - negacji takiego uregulowania, podważającej rację jego bytu w ramach systemu prawa. Analiza norm ustawowych z punktu widzenia ich zgodności z konstytucją służy zatem nie tylko wyznaczeniu zakresu dozwolonych działań ustawodawcy w aspekcie normowania relacji władza publiczna - jednostka, ale także działaniu na rzecz zagwarantowania jedności porządku prawnego.

Jedynie dla porządku formalnego należy podkreślić, że Konstytucja RP wyraźnie powiązała ideę jawności postępowania sądowego z prawem do sądu. W tym kontekście jawność funkcjonuje jako szczególna gwarancja tego prawa. Niezależnie od tego można - jak się wydaje - zasadnie twierdzić o wykreowaniu w art. 45 ust. 1 Konstytucji prawa do jawnego rozpatrzenia sprawy przez sąd ${ }^{5}$. Co ważne, art. 45 ust. 2 Konstytucji odnosi się już tylko do jawności, wskazując zestaw dopuszczalnych przyczyn wyłączenia jawności rozprawy oraz statuując regułę publicznego ogłoszenia wyroku.

Warto więc poddać analizie przepisy regulujące jawność rozprawy głównej w aspekcie konstytucyjnym, zwłaszcza że zasada jawności wcale nie jest odporna na oddziaływanie rozmaitych zjawisk prawnych i społecznych. W konsekwencji albo mamy do czynienia ze stanem dynamizmu prawnego, ponieważ ulegają zmianie przepisy normujące jawność rozprawy głównej, albo ze stanem dynamizmu faktycznego, gdy silnie dają znać o sobie przemiany społeczne, które jednak nie implikują modyfikacji normatywnych. W niniejszym artykule uwaga zostanie skierowana wyłącznie na te regulacje prawne, które wzbudzają określone wątpliwości z punktu widzenia ich zgodności z Konstytucją (niezależnie od wyniku analiz).

W pierwszej kolejności trzeba poddać analizie przepis art. 360 § 2 k.p.k. Jego treść jest konsekwencją zmian legislacyjnych objętych ustawą z dnia

${ }^{5}$ Szerzej na ten temat zob. R. KOPER: Jawność rozprawy głównej a ochrona prawa do prywatności $w$ procesie karnym. Warszawa 2010, s. 33-39. Por. J. SKoruPKA: Prawnomiędzynarodowe i konstytucyjne podstawy jawności procesu karnego. W: Jawność procesu karnego. Red. J. SкоRUPKA. Warszawa 2012, s. 88-94. 
10 czerwca 2016 r. $^{6}$. W myśl powołanego przepisu, jeśli prokurator sprzeciwi się wyłączeniu jawności rozprawy, odbywa się ona jawnie.

Zauważyć należy, że wykreowano tutaj szczególne uprawnienie przysługujące wyłącznie prokuratorowi, które to uprawnienie nie stanowi jednak jakiegokolwiek środka zaskarżenia. Omawiany sprzeciw to $\mathrm{w}$ istocie zawoalowana forma zgody uczestnika procesu na zastosowanie określonej instytucji proceduralnej. Należy wszak doprecyzować, że owa zgoda lub jej brak mają znaczenie decydujące w aspekcie dopuszczalności wyłączenia jawności rozprawy. Wykładnia literalna art. 360 § 2 k.p.k. pozwala bowiem na przyjęcie jedynie takiego sposobu interpretacji tego przepisu, który akcentuje związanie sądu stanowiskiem prokuratora $\mathrm{w}$ przedmiocie wyłączenia jawności rozprawy. W rozważanym przepisie owo uprawnienie prokuratora zostało ukształtowane jako kategoryczne, ostatecznie przesądzające o dopuszczalności wyłączenia jawności albo determinujące konieczność prowadzenia jawnej rozprawy. W tym sensie oznacza to, że prokurator uzyskał uprawnienie do modyfikacji projektowanej decyzji sądu. Przed podjęciem decyzji w przedmiocie wyłączenia jawności sąd powinien zwrócić się do prokuratora obecnego na rozprawie o zajęcie stanowiska $\mathrm{w}$ tej kwestii ${ }^{7}$. Za takim rozwiązaniem przemawia wykładnia językowa i logiczna. Prokurator nie ma jednak obowiązku uzasadnienia swego sprzeciwu, gdyż ustawodawca nie nałożył nań takiego wymogu, co stanowi wyraźną różnicę w stosunku do sądu wydającego postanowienie o wyłączeniu jawności rozprawy ${ }^{8}$. Wydaje się, że nowa treść art. 360 $\S 2$ k.p.k. oznacza de facto modyfikację modelu obowiązywania zasady jawności w odniesieniu do rozprawy głównej.

Podejmując próbę oceny tego nowego rozwiązania, trzeba mocno podkreślić, że problem, jaki tutaj powstaje, jest wieloznaczny.

Ustawodawca w uzasadnieniu do powołanej wyżej ustawy nowelizacyjnej z 2016 r. powołał się na fakt pełnienia przez prokuratora funkcji rzecznika praworządności ${ }^{9}$. Trudno to stwierdzenie poddać kontestacji, bo nie ma wątpliwości, że na etapie postępowania sądowego prokurator

${ }^{6}$ Ustawa o zmianie ustawy - Kodeks postępowania karnego, ustawy o zawodach lekarza i lekarza dentysty oraz ustawy o prawach pacjenta i Rzeczniku Praw Pacjenta, Dz.U. 2016, poz. 1070.

${ }^{7}$ W. JAsIŃsKI. W: Kodeks postępowania karnego. Komentarz. Red. J. SKORUPKA. Warszawa 2016, s. 887-888.

${ }^{8}$ M. BŁaszyK, H. PaluszKiewicz: Jawność rozprawy głównej po nowelizacji kodeksu postępowania karnego. W: Verba volant. Scripta manent. Proces karny, prawo karne skarbowe i prawo wykroczeń po zmianach z lat 2015-2016. Księga pamiątkowa poświęcona Profesor Monice Zbrojewskiej. Red. T. GrzegorczYK, R. OlszEwsKi. Warszawa 2017, s. 301; W. JasIŃsKi. W: Kodeks postępowania karnego. Komentarz..., s. 888.

${ }^{9}$ To uzasadnienie poniekąd odtwarzają: A. WAżNY. W: Kodeks postępowania karnego. Komentarz. Red. A. SAKowicz. Warszawa 2016, s. 847; M. Zimna: Wyłączenie jawności 
ma obowiązek występować w obronie interesu społecznego jako uczestnik tego postępowania o szczególnym statusie. Idąc tym tokiem rozumowania, można rozważać przyznanie prokuratorowi uprawnienia w zakresie współdecydowania o zakresie poszanowania jawności rozprawy.

Bliższa analiza tego problemu pozwala na sformułowanie określonych wątpliwości. Nikt nie jest w stanie zakwestionować faktu, że w płaszczyźnie formalnoprawnej na etapie postępowania jurysdykcyjnego prokurator występuje w roli strony, co prawda szczególnej, ale w dalszym ciągu strony procesowej. Uwagę zwraca fakt, że - jak już wyżej zaakcentowano - prokurator jest jedyną stroną procesową wyposażoną w tak „silne” uprawnienie. Pominięto w tym zakresie oskarżonego, a nawet pokrzywdzonego będącego oskarżycielem posiłkowym. Tok niniejszych wywodów nie zmierza bynajmniej do postulowania analogicznej zmiany w odniesieniu do wymienionych podmiotów, ale do wskazania pierwszego zasadniczego zastrzeżenia. Jest bowiem niewątpliwe, że alternatywa: jawność rozprawy albo jej brak może mieć pierwszorzędne znaczenie dla oskarżonego czy w mniejszym stopniu pokrzywdzonego z punktu widzenia stworzenia optymalnych warunków do prowadzenia sporu mającego doprowadzić do wydania najkorzystniejszego rozstrzygnięcia o przedmiocie procesu. W wypadku oskarżonego mocno uwidacznia się tutaj konieczność realizacji prawa do obrony, a w wypadku pokrzywdzonego - ogólnie rozumiana potrzeba realizacji interesu prawnego. Skoro zatem inne strony nie zostały wyposażone $\mathrm{w}$ analogiczne uprawnienie, podczas gdy kwestia zakresu respektowania jawności rozprawy nie jest dla nich obojętna w sensie realizacji ich interesów prawnych, ustawodawca wprowadza wyłom $\mathrm{w}$ zakresie realizacji reguły równości broni ${ }^{10}$ (w wypadku oskarżonego), czy w ogóle zapewnienia w sensie formalnoprawnym wszystkim stronom swobody w zakresie prowadzenia sporu i odpowiednich warunków do korzystania z dobrodziejstw kontradyktoryjnego procesu. W tym kontekście można zatem mówić o pewnym naruszeniu równowagi na etapie postępowania przed sądem. Sytuację pogarsza fakt, że na prokuratorze nie ciąży obowiązek uzasadnienia sprzeciwu, co z kolei oznacza, że pojawia się ryzyko arbitralnego działania prokuratora, który korzystając z nieograniczonego zakresu swobody, rozstrzyga relatywnie o sytuacji prawnej innych stron, a nawet uczestników procesowych nieposiadających statusu strony (świadek).

Warto też podkreślić, że omawiany sprzeciw dotyczy wszystkich podstaw wyłączenia jawności rozprawy wyszczególnionych w art. 360

rozprawy jako gwarancja ochrony interesów uczestników postępowania karnego. Prok. i Pr. 2016, nr 9, s. 99.

${ }^{10}$ Tak również W. JasińsKi. W: Kodeks postępowania karnego. Komentarz..., s. 888. 
$\S 1$ k.p.k. W rezultacie odnosi się także do tych przesłanek wyłączenia jawności, które wiążą się z ochroną dóbr osobistych oskarżonego, pokrzywdzonego czy świadka (np. obawa obrażenia dobrych obyczajów, obawa naruszenia ważnego interesu prywatnego). Realna staje się więc obawa zbyt daleko idącej ingerencji w sferę prywatności lub czci wymienionych podmiotów, i to warunkach objętych bardzo szerokim marginesem dyskrecjonalnej oceny. To ryzyko może być szczególnie zauważalne w wypadku pokrzywdzonego. Może się bowiem zdarzyć, że pokrzywdzony złoży wniosek o wyłączenie jawności rozprawy z uwagi na konieczność ujawnienia dotyczących go informacji o charakterze prywatnym (lub nawet intymnym, a zatem ściśle osobistym), natomiast sprzeciw prokuratora zniweczy możliwość prowadzenia rozprawy przy drzwiach zamkniętych (art. $360 § 1$ pkt 1 lit. d k.p.k.). Analogiczne ryzyko może być dotkliwe także dla innych uczestników procesu.

Nasuwa się wniosek, że prokurator otrzymał status gwaranta jawności rozprawy głównej. W tym kontekście staje się on także gwarantem respektowania interesów prawnych innych uczestników procesu, w tym ochrony ich dóbr osobistych (oczywiście na tle jawności rozprawy). Z kolei formułując sprzeciw wiążący dla sądu, prokurator jest w stanie podważyć rolę sądu jako organu prowadzącego postępowanie jurysdykcyjne i posiadającego na tym etapie pozycję nadrzędną. A ponieważ rozstrzygnięcie dylematu: jawne czy niejawne rozpoznanie sprawy łączy się z rozstrzygnięciem konfliktu wartości, często antynomicznych i konkurencyjnych ${ }^{11}$, o wyłączeniu jawności rozprawy powinien decydować sąd jako organ niezależny i bezstronny. Te cechy ze swej istoty nie znamionują prokuratora $\mathrm{w}$ postępowaniu sądowym, gdyż występuje on wówczas jako jedna ze stron stosunku prawnego. Za przyznaniem sądowi ostatecznego głosu w sprawie zakresu poszanowania jawności rozprawy przemawia jeszcze jedna okoliczność. To sąd, podejmując rozstrzygnięcie co do przedmiotu procesu, odpowiada w ostatecznym rozrachunku za realizację celów postępowania (art. 2 k.p.k.), a zatem powinien odpowiadać także z tytułu urzeczywistnienia funkcji zasady jawności, skoro między tymi celami i funkcjami zachodzi nierozerwalny związek. Innymi słowy, realizacja zadań przypisywanych jawności lub relatywne odstąpienie od ich realizacji nie jest i nigdy nie były kwestiami indyferentnymi z punktu widzenia konieczności osiągnięcia celów postępowania jako takiego.

Wydaje się, że powstają wątpliwości co do zgodności art. 360 § 2 k.p.k. z Konstytucją. Rzecz tyczy się prawa do sprawiedliwego rozstrzygnięcia sprawy przez sąd w rozumieniu art. 45 ust. 1 Konstytucji. Jest to niezbędny element treściowy prawa do sądu, co wielokrotnie podkreślał TK w swym

${ }^{11} \mathrm{Na}$ co celnie zwraca uwagę W. JASIŃSKI - ibidem. 
orzecznictwie $^{12}$. Jak wskazuje też TK, każde postępowanie przed sądem musi być ukształtowane zgodnie z zasadami sprawiedliwości, przy czym chodzi tutaj o zapewnienie stronom uprawnień procesowych stosownie do przedmiotu postępowania ${ }^{13}$. Prawo do odpowiedniego ukształtowania procedury sądowej zgodnie $\mathrm{z}$ wymogiem sprawiedliwości obejmuje zapewnienie skutecznej ochrony praw stron $\mathrm{w}$ warunkach obowiązywania zasady kontradyktoryjności ${ }^{14}$. Sprawiedliwość proceduralna jako wartość uniwersalna oznacza m.in. przewidywalność działań organów procesowych przez odpowiednią spójność i wewnętrzną logikę mechanizmów, którym dany uczestnik postępowania jest poddany ${ }^{15}$. Dotyczy ona celu postępowania i w tym aspekcie w myśl art. 45 ust. 1 Konstytucji każdemu przysługuje prawo do orzeczenia w sprawie, ale z zachowaniem podstawowych gwarancji umożliwiających urzeczywistnienie takiego stanu ${ }^{16}$.

Regulacja art. 360 §2 k.p.k. nie stwarza gwarancji tego rodzaju, ponieważ o niebagatelnej na ogół kwestii w postaci rozstrzygania o jawności lub jej braku, powiązanej ze stworzeniem optymalnych warunków do wydania orzeczenia w sprawie, decyduje jedna ze stron postępowania, a tym samym podmiot pozbawiony atrybutu niezależności i bezstronności, a na dodatek dzieje się to w warunkach świadczących o możliwości arbitralnego decydowania. Nie da się zatem w tym kontekście twierdzić o umożliwieniu utrzymywania zaufania uczestników procesu do tak ukształtowanej procedury, gdyż oddanie w ręce prokuratora kwestii zakresu respektowania jawności rozprawy osłabia w tym aspekcie stan zaufania. Strony procesowe stają się tutaj całkowicie uzależnione od decyzji innej strony postępowania, z pominięciem kierowniczej roli sądu jako organu powołanego w sposób naturalny do zabezpieczenia przed naruszaniem praw i wolności oraz nakładaniem na jednostkę niewspółmiernych obowiązków. Istota kontradyktoryjności zostaje zachwiana w następstwie swoistego pomieszania ról procesowych. Wszak prawo do sprawiedliwego rozstrzygnięcia sprawy może mieć sens o tyle, o ile sąd jest w stanie zapewnić odpowiednie warunki do rozstrzygania sprawy w rozumieniu art. 45 ust. 1 Konstytucji, czyli ma możliwość zagwarantowania tych warunków w swym orzekaniu. W przeciwnym razie standard prawa do sądu ulega relatywnemu osłabieniu. Niezapewnienie należytych warunków rozpoznania sprawy przed są-

\footnotetext{
${ }_{12}$ Np. wyrok TK z dnia 9 czerwca 1998 r., K 28/97, OTK 1998, nr 4, poz. 50; wyrok TK z dnia 16 marca 1999 r., SK 19/98, OTK 1999, nr 3, poz. 36.

${ }^{13}$ Wyrok TK z dnia 11 czerwca 2002 r., SK 5/02, OTK-A 2002, nr 4, poz. 84, wyrok cytowany i omówiony przez P. Wilińskiego w: Rzetelny proces karny $w$ orzecznictwie sądów polskich i międzynarodowych. Red. P. Wiliński. Warszawa 2009, s. 304, 311.

${ }^{14}$ P. WiLIŃsKI: Proces karny w świetle Konstytucji. Warszawa 2011, s. 119-120.

${ }^{15}$ Ibidem, s. 100.

${ }^{16}$ Ibidem, s. 106.
} 
dem odbywa się w tym wypadku w sytuacji stwarzającej zagrożenie ochrony praw i wolności uczestników postępowania.

Należy jeszcze podkreślić, że w treści art. 45 ust. 1 Konstytucji znajduje swe dopełnienie pojęcie wymiaru sprawiedliwości, do którego w kontekście działalności sądów odwołuje się art. 175 ust. 1 Konstytucji ${ }^{17}$. Co prawda drugi z przytoczonych przepisów nie tworzy w analizowanej sytuacji bezpośredniego odniesienia, niemniej jednak wyznacza dodatkową perspektywę, którą też należy uwzględniać. Jeśli bowiem wymiar sprawiedliwości odczytujemy przez pryzmat pojęcia sprawy w rozumieniu art. 45 ust. 1 Konstytucji, to nie ma wątpliwości, że wzrasta ranga zadania ustawodawcy zobowiązanego do adekwatnego (tzn. zgodnego z Konstytucją) uwzględnienia prawa do odpowiednio ukształtowanej procedury sądowej.

Powstaje pytanie: w jaki sposób osiągnać ten stan rzeczy, który prawdopodobnie zamierzano osiągnąć, wprowadzając przepis art. 360 §2 k.p.k. $\mathrm{w}$ aktualnym brzmieniu? Wydaje się, że chodziło o wyeliminowanie ryzyka arbitralności decyzji sądowej w przedmiocie wyłączenia jawności rozprawy.

$\mathrm{Z}$ jednej strony chyba nie ma potrzeby działania w tym kierunku. Sędziowie raczej dość powściagliwie podejmują decyzje w tej kwestii, a nawet można odnieść wrażenie, że pryncypialnie postrzegają zasadę jawności, chcąc w ten sposób bronić się przez ewentualnymi zarzutami uchybień lub nieprawidłowości ${ }^{18}$ i zarazem odczuwając głęboko zakorzenioną potrzebę zderzenia się z opinią publiczną. $Z$ drugiej strony zapewne nie da się całkowicie wyeliminować ryzyka arbitralności podczas podejmowania decyzji przez sąd. Praktycznie jedynym remedium w tym zakresie może być rozważenie możliwości składania zażalenia na postanowienie sądu dotyczące wyłączenia jawności rozprawy. W tym też kierunku zmierzała pierwotna wersja projektu ustawy nowelizacyjnej z dnia 10 czerwca 2016 r. ${ }^{19}$. Trzeba jednak rzetelnie przyznać, że jest to rozwiązanie dyskusyjne i kontrowersyjne. Wprawdzie art. 13 Europejskiej Konwencji Praw Człowieka wymusza potrzebę istnienia skutecznego środka odwoławczego tam, gdzie już doszło do naruszenia praw i wolności zagwarantowanych przez EKPC, a zatem dotyczy to naruszenia tych uprawnień w następstwie przeprowadzenia jawnej rozprawy, podczas gdy zadekretowanie możliwości wnoszenia zażalenia na samo postanowienie w przedmiocie wyłączenia jawności

${ }^{17} \mathrm{Na}$ temat wzajemnych relacji między obydwoma przepisami zob. np. L. GarLICKI: Komentarz do art. 175 Konstytucji. W: Konstytucja Rzeczypospolitej Polskiej. Komentarz. Warszawa 2005, s. 5-6; P. Wiliński, P. KARLIK. W: Konstytucja RP. Komentarz. Red. M. SAfJAN, L. BoseK. T. II: Art. 87-243. Warszawa 2016, s. 978 i powołane tam orzecznictwo.

${ }^{18}$ H. Jung: Zasada jawności w postępowaniu karnym RFN. Probl. Prawa Karnego 1988, nr 14 , s. 19.

${ }^{19} \mathrm{Na}$ ten temat zob. A. WAżNy. W: Kodeks postępowania karnego. Komentarz..., s. 847. 
odnosiłoby się do innego kontekstu sytuacyjnego, nie mówiąc o tym, że wywołałoby sporo zamieszania i działałoby na rzecz wydłużenia postępowania ${ }^{20}$. Jak widać - problem jest niełatwy w rozstrzygnięciu, zaś bliższa jego analiza przekracza ramy niniejszego opracowania ${ }^{21}$.

Druga regulacja ustawowa objęta zakresem analiz została unormowana w art. 357 k.p.k. Rzecz tyczy się rejestrowania przebiegu rozprawy za pomocą aparatury utrwalającej obraz i dźwięk. Także w tym wypadku kształt stosownego uregulowania uległ zmianie w następstwie wejścia w życie wspomnianej ustawy nowelizacyjnej z dnia 10 czerwca 2016 r.

Warto zauważyć, że pod rządem poprzednio obowiązujących przepisów rejestracja audiowizualna była dopuszczalna, gdy zezwolenia $\mathrm{w}$ tej mierze udzielił sąd analizujący spełnienie trzech warunków: 1) musiał za tym przemawiać uzasadniony interes społeczny, 2) taka rejestracja nie mogła utrudniać prowadzenia rozprawy, 3) nie wystąpiła przeszkoda w postaci uwzględnienia ważnego interesu uczestnika postępowania. Wydaje się, że było to rozwiązanie kompromisowe i zarazem udane, próbujące pogodzić sprzeczne dobra i interesy ${ }^{22}$.

De lege lata stylizacja art. 357 \$ 1 k.p.k. wprost wskazuje, że kompetencja sądu w zakresie zezwolenia na rejestrację audiowizualną zmienia swój charakter, gdyż staje się obligatoryjna, co oznacza, że sąd ma obowiązek dopuścić przedstawicieli środków społecznego przekazu do rozprawy, jeśli tylko zwrócą się oni do sądu o wydanie takiego zezwolenia. Rejestracja audiowizualna staje się już bardziej regułą w tym sensie, że to dziennikarze dokonują wyboru spraw karnych, które będą relacjonowane w tym szczególnym trybie, bo wystarczy złożenie przez nich stosownego wniosku do sądu, który musi wniosek uwzględnić. W takim układzie sąd nie przeprowadza już oceny wniosku złożonego przez przedstawicieli mediów ${ }^{23}$. Inaczej mówiąc, sąd jest w dużym stopniu takim wnioskiem związany.

\footnotetext{
${ }^{20}$ Szeroko na ten temat R. Koper: Jawność rozprawy..., s. 313-317. Por. nadto K. Nowicki: Jawność zewnętrzna postępowania sq̨dowego. W: Jawność procesu karnego. Red. J. SKoRUPKA. Warszawa 2012, s. 368-370.

${ }^{21}$ Problemu raczej nie załatwi wprowadzenie możliwości wnoszenia odwołania od sprzeciwu prokuratora do sądu, a to z uwagi na fakt, że zgoda prokuratora lub jej brak nie stanowią rozstrzygnięcia ujętego w ramy decyzji procesowej. Wprawdzie k.p.k. zna wypadki składania środka zaskarżenia na czynność faktyczną lub nawet na zaniechanie czynności (art. 467 § 1 k.p.k.), ale nie wydaje się, aby w rozważanej sytuacji było to rozwiązanie w pełni adekwatne. Wspomnianą możliwość odwołania od sprzeciwu dopuszcza M. Zimna zob. M. Zimna: Wyłączenie jawności rozprawy jako gwarancja ochrony interesów..., s. 99.

${ }^{22}$ R. Koper: Jawność zewnętrzna postępowania sądowego. W: Jawność jako wymóg rzetelnego procesu karnego. Zagadnienia prawa polskiego i obcego. Red. W. JAsIŃsKI, K. NowICKI. Warszawa 2013, s. 112.

${ }^{23}$ M. BeaszyK, H. PaluszKieWicz: Jawność rozprawy głównej..., s. 303.
} 
Analiza treści art. 357 k.p.k. prowadzi do wniosku, że jedynym warunkiem dopuszczalności rejestracji audiowizualnej, czyli jedyną przesłanką zdatną wyłączyć lub ograniczyć możliwość jej przeprowadzenia, są powody techniczno-organizacyjne. Krótko mówiąc, chodzi o to, że dokonywanie utrwaleń obrazu i dźwięku będzie utrudniać prowadzenie rozprawy. O tego rodzaju powodach wspomina się wprost w art. 357 \$3 k.p.k. Mogą one stanowić podstawę zarządzenia wydawanego w trybie art. 357 \$ k.p.k., a ponadto wydaje się, że takie względy wypełniają treść wyrażenia językowego „sąd może określić warunki udziału” w rozumieniu art. 357 § 2 k.p.k.

Nie jest potrzebna wnikliwa obserwacja, aby zauważyć, że $\mathrm{w}$ treści art. 357 k.p.k. nie wymaga się już analizy uzasadnionego interesu społecznego. Ustawodawca $\mathrm{w}$ ramach uzasadnienia omawianej zmiany argumentował, że zachodzi konieczność wzmocnienia transparentności procesu karnego w wyniku zapewnienia kontroli społecznej nad prawidłowością przebiegu postępowania, a biorąc także pod uwagę kontekst dotyczący społeczeństwa informacyjnego, ex definitione za tym nowym rozwiązaniem przemawia uzasadniony interes społeczny ${ }^{24}$. Należy mocno zaakcentować, że te tezy są w swej istocie trafne, gdyż nie sposób nie dostrzegać rozwoju społeczeństwa informacyjnego. Jeśli jednak punktem odniesienia dla tych słusznych założeń jest gwałtowna ekspansja mediów elektronicznych, to pojawiają się określone zastrzeżenia związane z niską nierzadko jakością realizacji funkcji informacyjnej prasy w Internecie. Z drugiej strony można też zapewne kontrargumentować, że wady tej sytuacji muszą być usuwane innymi metodami czy sposobami, podczas gdy rozwój mediów elektronicznych jest faktem i z tym należy się pogodzić. Postęp technologiczny i potrzeby „globalnej wioski” zmodyfikowały reguły i obyczaje dotyczące jawności pośredniej do tego stopnia, że nawet mówi się niekiedy o zastąpieniu tej formy jawności ,jawnością techniczną"25.

Na gruncie poprzedniego stanu prawnego wymóg istnienia uzasadnionego interesu społecznego stanowił wszakże tamę przed wystąpieniem negatywnego zjawiska kulturowego polegającego na nieracjonalnym czy emocjonalnym zainteresowaniu społecznym określonymi sprawami karnymi. We włoskiej literaturze karnoprocesowej i orzecznictwie wyraźnie przyjmuje się, że interes społeczny nie może być zamienny z ciekawością dotyczącą zdarzeń prywatnych, a element powszechnej znajomości oskarżonego bez jakiegokolwiek odniesienia w obciążających go faktach nie jest wystarczający $\mathrm{w}$ wydaniu sądowego zezwolenia na omawianą for-

${ }^{24} \mathrm{Na}$ tę argumentację powołuje się A. WAŻNY. W: Kodeks postępowania karnego. Komentarz..., s. 844.

${ }^{25}$ Commento al codice di procedura penale. Red. P. Corso. Piacenza 2008, s. 3313. 
mę rejestracji ${ }^{26}$. Jeśli naczelną zasadą współczesnego dziennikarstwa jest zasada sensacyjności („newsowości”), to w warunkach normatywnych nowej regulacji art. 357 k.p.k. należy się spodziewać zwiększonego zainteresowania ze strony prasy tymi właśnie sprawami, w których będzie można zaspokoić to swoiste, często „niezdrowe” zaciekawienie społeczne. Doszło chyba w ten sposób do prawnej legitymizacji owego nieuzasadnionego zainteresowania społecznego. Z drugiej strony także w tym wypadku da się kontrargumentować, że sygnalizowane zjawisko nie jest nowe, a punkt ciężkości wypadałoby przesunąć w stronę analizy dotyczącej sposobów neutralizacji tego zjawiska. Być może zwiększony dostęp społeczeństwa do rozpraw karnych sprawi, że zacznie być dostrzegalna zarówno ta szkodliwa, jak i odpowiedzialna strona przestępstwa, tzn. wynikająca z uwzględnienia elementów edukacyjnych czy związanych z kształtowaniem świadomości prawnej i moralnej. Poza tym mimo wszystko dziennikarze wykazują zainteresowanie niektórymi sprawami karnymi ${ }^{27}$.

W wyniku wejścia w życie powołanej wyżej ustawy nowelizacyjnej ważny interes uczestnika postępowania również nie stanowi już warunku dopuszczalności rejestracji audiowizualnej. Jedynym znakiem respektowania tego interesu jest unormowanie art. 357 \$5 k.p.k., w którym to przepisie zadekretowano wyjątkową możliwość zarządzenia opuszczenia sali rozpraw przez przedstawicieli prasy na czas przesłuchania świadka, gdy zachodzi obawa, że ich obecność mogłaby oddziaływać krępująco na jego zeznania. Otwarta pozostaje natomiast kwestia ochrony dóbr osobistych uczestników procesu. W zasadzie mogłoby się wydawać, że żadnego niebezpieczeństwa tutaj nie ma. Obowiązuje zakaz publikacji w prasie danych osobowych i wizerunku oskarżonego, pokrzywdzonego i świadka (art. 13 ust. 2 ustawy - Prawo prasowe), który to zakaz pozostaje niezależny w stosunku do zezwolenia na rejestrację audiowizualną $\mathrm{w}$ rozumieniu art. $357 \$ 1$ k.p.k. Wprawdzie ta kwestia nie jest jednoznaczna, ale za trafny trzeba uznać dominujący w doktrynie pogląd, że art. 357 k.p.k. dotyczy tylko rejestracji rozprawy, a nie publikacji utrwalonych $\mathrm{w}$ ten sposób treści, zaś art. 13 ust. 2 Prawa prasowego wprowadza ograniczenia w sferze publikowania ${ }^{28}$. Trzeba wszak zauważyć, że dziennikarze nie mogą publikować określonych informacji, ale nic nie stoi na przeszkodzie, aby je ujawniali w formie, która nie będzie rozpowszechnianiem (czyli nie będzie polegać na publikowaniu). I tu można kontrargumentować, że zakres szkodliwości tego zjawiska może nie mieć szerokiego odzwiercie-

${ }^{26}$ Ibidem, s. 3315, 3317.

${ }^{27}$ A. GERECKA-ŻoŁYŃsKA, P. GóRECKI: Rola środków społecznego przekazu na tle zasady domniemania niewinności. W: Europejskie standardy ochrony praw człowieka a ustawodawstwo polskie. Red. E. Dynia, Cz.P. KŁaK. Rzeszów 2005, s. 415.

${ }^{28}$ R. Koper: Jawność rozprawy..., s. 342-345 i wskazana tam literatura. 
dlenia. Może się także zdarzyć, że dziennikarz zdecyduje się opublikować dane osobowe i wizerunek, czyli naruszyć zakaz statuowany w art. 13 ust. 2 Prawa prasowego, w szczególności gdy kryją się za nimi informacje „atrakcyjne” w sensie komercyjnym. Nie są to obawy przesadzone - takie przypadki w polskiej rzeczywistości prasowej już miały miejsce. Wówczas relacja prasowa z procesu tworzy stan tzw. neorealizmu telewizyjnego, czyli dochodzi do tego, że postępowanie przed sądem zamienia się w degradującą scenę, na której występują obywatele uwikłani w proces ${ }^{29}$.

Podejmując próbę oceny uregulowania art. 357 k.p.k. w relacji do norm konstytucyjnych, należy zaryzykować twierdzenie, że jest to przepis zgodny z Konstytucją. Zważyć wszak należy, że wyszczególnione ujemne aspekty ewentualnego stosowania art. 357 k.p.k. bardziej tkwią w negatywnych zjawiskach socjo-kulturowych lub w praktyce medialnej. Gdyby oczekiwać wyeliminowania lub przynajmniej ograniczenia występowania tych zjawisk w przestrzeni społecznej albo gdyby oczekiwać od dziennikarzy skrupulatnego i uważnego przestrzegania obowiązujących przepisów, wówczas ostrze krytyki zostałoby mocno stępione. Mamy do czynienia z sytuacją, gdy przepis ustawowy - sam w sobie - nie jest może idealny, ale jest do obrony w świetle przepisów Konstytucji. Opierając się o normy konstytucyjne, dałoby się zapewne wykazać, że poszerzenie zakresu dopuszczalnego rejestrowania przebiegu rozprawy w trybie art. 357 k.p.k. leży $\mathrm{w}$ interesie społecznym, co ma istotne znaczenie $\mathrm{w}$ dobie rozwoju społeczeństwa informacyjnego. Aktywność informacyjna nigdy nie jest kulturowo obojętna, a skoro jest konstytucyjnie zagwarantowana, ma przyczyniać się do rozwoju człowieka i jego efektywnego udziału w życiu wspólnym ${ }^{30}$. Inaczej mówiąc, przepis nie budzi wątpliwości w aspekcie Konstytucji, natomiast niewłaściwa jest praktyka medialna jako konsekwencja zastosowania tego przepisu. Można co prawda rozważać wprowadzenie do art. 357 k.p.k. warunku ochrony ważnego interesu indywidualnego, bo byłoby to zasadne w kontekście powyższych wywodów, ale brak takiej przesłanki w sensie normatywnym też raczej nie oddziałuje $\mathrm{w}$ stronę stwierdzenia niekonstytucyjności tego przepisu.

Wątpliwości natury konstytucyjnej wzbudza jeszcze norma zawarta w art. 13 ust. 3 Prawa prasowego. Chodzi w zasadzie o brak regulacji normatywnej odnoszącej się do możliwości uchylenia zakazu prasowej publikacji danych osobowych i wizerunku w stosunku do osób publicznych. W tej mierze jest zauważalny wyjątkowy $\operatorname{chaos}^{31}$, bo zdarzają się

${ }^{29}$ Tak metaforycznie, z powołaniem się na orzecznictwo włoskich sądów: A. BeVERE, A. CERRI: Il diritto di informazione e i diritti della persona. Milano 1995, s. 126; A. SCALISI: Il diritto alla riservatezza. Milano 2002, s. 467.

${ }^{30}$ C. Ridolfi: Persona e mass media. Padova 1990, s. 97.

${ }^{31}$ R. Koper: Jawność zewnętrzna..., s. 114. 
przypadki samowolnego upublicznienia takich danych przez dziennikarzy, pomimo braku zezwolenia prokuratora lub sądu albo sytuacje, w których następuje uchylenie tego zakazu przez organ procesowy w wyniku automatycznego (czyli błędnego) postawienia znaku równości między statusem osoby publicznej a ważnym interesem społecznym wymaganym przez art. 13 ust. 3 Prawa prasowego. Tymczasem zakaz określony w art. 13 ust. 2 ustawy prasowej dotyczy także osób publicznych, ponieważ nie doszło do wyłączenia tej kategorii podmiotów spod zakresu jego obowiązywania. W rozważanej sytuacji nie chodzi więc tylko o niewłaściwą praktykę, lecz problem jest głębszy, ponieważ immanentnie tkwi $\mathrm{w}$ zaniechaniu ustawodawczym. Inaczej ujmując tę myśl - zaniechanie legislacyjne sprzyja petryfikacji niewłaściwego zakresu ochrony dóbr osobistych osób publicznych. Jest, a przynajmniej powinno być, oczywiste, że także osoby publiczne korzystają z ochrony prywatności i wizerunku, choć granice tej ochrony są in abstracto zawężone. Granice zacieśnienia tej ochrony musi wskazać ustawodawca podczas normowania regulacji ustawowych zezwalających na ingerencję in concreto. W konsekwencji ingerencja w sferę dóbr osobistych tych osób powinna odnajdywać wyraźną podstawę prawną, zwłaszcza poprzez wskazanie, które kategorie osób w ramach zróżnicowanej grupy osób publicznych i przy spełnieniu jakich warunków podlegają zmniejszonej ochronie prywatności i wizerunku (tak jak to ma miejsce np. w art. 14 ust. 6 Prawa prasowego, art. 81 ust. 2 pkt 1 ustawy o prawie autorskim i prawach pokrewnych). Chodzi o zagwarantowanie pewności prawnej, która będzie sprzyjać właściwemu ukształtowaniu ochrony prywatności (art. 47 i 51 Konstytucji) oraz z drugiej strony zapewni jednolitość w zakresie respektowania prawa obywateli do informacji o osobach pełniących funkcje publiczne w rozumieniu art. 61 Konstytucji ${ }^{32}$. Utrzymywanie obecnego stanu rzeczy, gdy nie jest to uporządkowane normatywnie, oznacza $\mathrm{w}$ wielu wypadkach nadmierne poświęcenie prywatności, powodujące uciążliwości, które nie pozostają w odpowiedniej proporcji do celu, jaki ma zostać zrealizowany (art. 31 ust. 3 Konstytucji).

W pozostałym zakresie przepisy normujące jawność rozprawy głównej nie wywołują zastrzeżeń o charakterze konstytucyjnym.

${ }^{32}$ Szeroko w tej kwestii R. Koper: Jawność rozprawy..., s. 405-411 i podana tam literatura. Por. W. JAsiŃski: Jawność zewnętrzna procesu karnego - uwagi na tle propozycji Komisji Kodyfikacyjnej Prawa Karnego. W: Jawność jako wymóg rzetelnego procesu karnego. Zagadnienia prawa polskiego i obcego. Red. W. JAsIŃsKI, K. NowicKI. Warszawa 2013, s. 135-136. 


\section{Bibliografia}

\section{Literatura}

Bevere A., Cerri A.: Il diritto di informazione e i diritti della persona. Milano 1995. BiAnCO R.: Il diritto del giornalismo. Padova 1997.

BŁaszyK M., PaluszKiewicz H.: Jawność rozprawy głównej po nowelizacji kodeksu postępowania karnego. W: Verba volant. Scripta manent. Proces karny, prawo karne skarbowe i prawo wykroczeń po zmianach z lat 2015-2016. Ksiegga pamiątkowa poświęcona Profesor Monice Zbrojewskiej. Red. T. GrzegorczyK, R. Olszewski. Warszawa 2017.

Ciappi M.: Pubblicità (principio della). „Digesto delle Discipline Penalistiche” 1995, nr 10.

Commento al codice di procedura penale. Red. P. Corso. Piacenza 2008.

GARLICKI L.: Komentarz do art. 175 Konstytucji. W: Konstytucja Rzeczypospolitej Polskiej. Komentarz. Warszawa 2005.

GERECKA-ŻoŁYŃsKa A., GóRECKI P.: Rola środków społecznego przekazu na tle zasady domniemania niewinności. W: Europejskie standardy ochrony praw człowieka a ustawodawstwo polskie. Red. E. Dynia, C.P. KŁaK. Rzeszów 2005.

GiUlani L.: Rimessione del processo e valori costituzionali. Torino 2002.

JAsiński W.: Jawność zewnętrzna procesu karnego - uwagi na tle propozycji Komisji Kodyfikacyjnej Prawa Karnego. W: Jawność jako wymóg rzetelnego procesu karnego. Zagadnienia prawa polskiego i obcego. Red. W. JAsIŃsKI, K. NowicKI. Warszawa 2013.

JasińsKi W. W: Kodeks postępowania karnego. Komentarz. Red. J. SKorupKA. Warszawa 2016.

Jung H.: Zasada jawności w postępowaniu karnym RFN. Probl. Prawa Karnego 1988, nr 14.

KOPER R.: Jawność rozprawy głównej a ochrona prawa do prywatności $w$ procesie karnym. Warszawa 2010.

Koper R.: Jawność zewnętrzna postępowania sq̨dowego. W: Jawność jako wymóg rzetelnego procesu karnego. Zagadnienia prawa polskiego i obcego. Red. W. JAsIŃsKI, K. Nowicki. Warszawa 2013.

Manzione D. W: Commento al nuovo codice di procedura penale. Red. M. CHIAvario. T. V. Torino 1991.

Mercone M.: Diritto processuale penale. Milano 2000.

Nowicki K.: Jawność zewnętrzna postępowania sądowego. W: Jawność procesu karnego. Red. J. Skorupka. Warszawa 2012.

Ridolfi C: Persona e mass media. Padova 1990.

SCALISI A.: Il diritto alla riservatezza. Milano 2002.

SCOMPARIN L.: La tutela del testimone nel processo penale. Padova 2000.

SKORUPKA J.: Prawnomiędzynarodowe $i$ konstytucyjne podstawy jawności procesu karnego. W: Jawność procesu karnego. Red. J. SKORUPKA. Warszawa 2012.

Ubertis G.: Principi di procedura penale europea. Le regole del giusto processo. Milano 2000.

WAŻNy A. W: Kodeks postępowania karnego. Komentarz. Red. A. SAKowicz. Warszawa 2016. 
WiLIŃsKi P.: Proces karny $w$ świetle Konstytucji. Warszawa 2011.

WiLIŃsKi P. W: Rzetelny proces karny $w$ orzecznictwie sądów polskich i międzynarodowych. Red. P. Wiliński. Warszawa 2009.

Wiliński P., Karlik P. W: Konstytucja RP. Komentarz. Red. M. SafJan, L. BoseK. T. II: Art. 87-243. Warszawa 2016.

ZIMnA M.: Wyłączenie jawności rozprawy jako gwarancja ochrony interesów uczestników postępowania karnego. Prok. i Pr. 2016, nr 9.

\section{Orzecznictwo}

Wyrok TK z dnia 9 czerwca 1998 r., K 28/97, OTK 1998, nr 4, poz. 50.

Wyrok TK z dnia 16 marca 1999 r., SK 19/98, OTK 1999, nr 3, poz. 36.

Wyrok TK z dnia 11 czerwca 2002 r., SK 5/02, OTK-A 2002, nr 4, poz. 84. 